КРИВЕНКО Д.С.

\title{
ПОРІВНЯЛЬНО-ПРАВОВИЙ АНАЛІЗ МЕДІАЦІЇ ТА ТРУДОВОГО АРБІТРАЖУ ЯК СПОСОБУ ВИРІШЕННЯ ТРУДОВИХ СПОРІВ: СПІЛЬНІ ТА ВІДМІННІ РИСИ
}

\begin{abstract}
У статті проаналізовано специфіку способів вирішення трудових спорів. Основну увагу відведено безпосередньо характеристиці медіації та трудового арбітражу. Проведено порівняльно-правовий аналіз медіації та трудового арбітражу як способу вирішення трудових спорів. Досліджено спільні та відмінні риси зазначених правових категорій. Охарактеризовано сутність і значення кожної з них. Наголошено, що для вирішення трудових спорів варто повністю з'ясувати як позиції сторін, так і доказовий матеріал. Проте змога залучати свідків та експертів $є$ спірною, адже такий спосіб вирішення трудового спору використовують через швидкість й оперативність розгляду справи, а проведення експертних досліджень потребує тривалого часу як для самого дослідження, так і для формування висновку. Щодо свідків, то виникає питання щодо їхньої неупередженості та достовірності, адже гарантій безпеки реалізації трудових прав такого свідка не передбачено. 3'ясовано, що, на відміну від медіації, трудовий арбітраж може проводитись публічно, що дає змогу забезпечити відсутність тиску на будь-яку зі сторін трудового спору. Серед позитивних аспектів такого способу вирішення трудових спорів $€$ змога вносити пропозиції до рішення трудового арбітражу, адже це допомагає самим сторонам краще розібратись із сутністю спору та бажаним кінцевим результатом, а також й полегшує аналітичну роботу для арбітрів. Визначено, що рішення трудового арбітражу не володіє обов'язковою юридичною силою та викликатиме юридичні наслідки лише в разі спільного задоволення інтересів. У цьому контексті для роботодавця рішення трудового арбітра $є$ бажаним для виконання, якщо воно винесене на його користь або ж передбачає менші збитки, ніж судовий розгляд. Однак саме таке рішення може не вдовольняти трудовий колектив та профспілки, що означатиме або ж проведення страйку, або, власне, звернення до суду. Окремо варто зазначити обов'язок сторін повідомляти про власне рішення щодо намірів у виконанні, яке виступає гарантією права на інформацію та дає змогу вірно розуміти перспективи вирішення трудового спору та захисту своїх прав суб’єктами трудових відносин.

Ключові слова: порівняльно-правовий аналіз, медіація, трудовий арбітраж, трудові спори, способи вирішення трудових спорів.
\end{abstract}

In the article the specifics of ways to resolve labour disputes are analyzed. The main attention is paid directly to the characteristics of mediation and labour arbitration. A comparative legal analysis of mediation and labour arbitration as a way to resolve labour disputes. The common and distinctive features of these legal categories are studied. The essence and significance of each of them are described. Emphasizing that in order to reduce labour resources, people need to reduce both the position on the page and the evidence people. Test using your own experts and experts, they try to make work more efficient, and the speed of operation in the operating mode must be sure that it may take a long time to require a long time, both for their own use and for the necessary maintenance. As for the question, there is a question of their insecurity and reliability, which guarantee the safety of employees who really work. Due to the fact that it deviates from mediation, labour arbitration can be conducted in public, which allows you to find your own pressure on any side of the labour dispute. Other positive aspects that allow you to achieve higher results can be offered to resolve labour arbitration, but this means that it is best to deal with the dispute of the structure and the desired end result, as well as facilitated for

(C) КРИВЕНКО Д.Є. - аспірант кафедри трудового права та права соціального забезпечення юридичного факультету (Київський національний університет імені Тараса Шевченка) 
experts. Determined to decide a difficult arbitration that does not use, but it uses a legal entity that uses and uses legal entities that have used joint satisfaction. In this context, for the work to be decided by the working arbitrator, it is desirable to check when it is at the same time, and it should be more useful, or it has less damage, lower trial. However, this can also be decided by an imperfect workforce and their unions, which are meant to either seek a strike or, the owner, take it back to court. Separately, you should see a well-known page, which told about its own decision on intentions in production, which requires warranty rights to work and allows well-established prospects for improving the efficiency of labour disputes and the existence of their rights to labour relations.

Key words: comparative legal analysis, mediation, labour arbitration, labour disputes, ways of resolving labour disputes.

Вступ. Конституцією України передбачене існування права на захист, яке традиційно реалізується через звернення до суду. Проте в межах вирішення трудових спорів застосування виключно судових способів має обмежувальний характер та не завжди може сприяти вирішенню його по суті. 3 огляду на національну практику судового захисту трудових прав, стає зрозумілою проблема відсутності довіри до правоохоронних органів, а також велика завантаженість самих судів, що затримує розгляд справ навіть у спрощеному порядку. Саме тому необхідним є дослідження та порівняння усіх способів вирішення трудових спорів, як-от трудовий арбітраж, що можуть й мати позаюрисдикційний характер, однак допомагатимуть розглянути трудовий спір комплексно щодо його правових та емоційних складників, що, своєю чергою, надасть змогу зрозуміти суть самої проблеми, що стала причиною трудового спору. Крім того, порівняння таких способів вирішення трудових спорів із медіацією дасть змогу визначити ключові особливості їх застосування, а отже, можливість їх використання для вирішення усіх видів трудових спорів або ж виключно спеціалізованість й найбільшу ефективність для таких видів, як індивідуальні спори чи спори щодо зміни умов колективного договору.

Через тривалу історію переважання виключно судового порядку порівняння різних способів вирішення трудових спорів залишається малодослідженою темою, однак окремими її питаннями щодо сутності або місця окремих способів займались такі вчені: В.С. Балух, В.А. Багрій, В.Я. Буряк, Н.Д. Гетьманцева, Г.М. Грабовська, В.М. Дайнека, О.А. Дутко, С.І. Запара, М.І. Іншин, В.О. Кабанець, О.В. Кузніченко, Л.В. Кулачок-Тітова, І.В. Лагутіна, М.А. Мацько, К.Ю. Мельник, Д.О. Новіков, А.О. Підгорна, О.Г. Середа, Н.В. Уварова, О.А. Шурин, А.В. Яресько та інші.

Результати дослідження. Варто наголосити, що нині українським законодавством передбачено застосування трудового арбітражу виключно для колективних трудових спорів. Проте міжнародна практика свідчить про застосування такого способу і для індивідуальних, що, своєю чергою, свідчить про перспективний напрям законодавчого врегулювання.

Насамперед, варто звернути увагу на ст. 15 Закону України «Про порядок вирішення колективних трудових спорів (конфліктів)», де визначено, що «з метою сприяння поліпшенню трудових відносин та запобігання виникненню колективних трудових спорів (конфліктів), їх прогнозування та сприяння своєчасному їх вирішенню, здійснення посередництва для вирішення таких спорів (конфліктів) Президентом України утворюється Національна служба посередництва і примирення» [1]. Тобто однією з перших гарантій проведення трудового арбітражу є сприяння та нагляд із боку держави. Діяльність цього органу має регулюючий характер, адже саме нею видаються окремі накази щодо діяльності арбітра, регламенту трудового арбітражу та порядку прийняття рішень. Також саме цим органом і здійснюється контроль за дотриманням сторонами встановленого порядку. Разом із тим дещо суперечливою $є$ сама потреба в залученні держави, адже трудовий арбітраж як спосіб вирішення трудових конфліктів має добровільний та диспозитивний характер. Водночас залучення держави робить такий процес максимально наближеним до судового розгляду.

До такого ж висновку можна дійти, аналізуючи думку В.О. Кабанець, що для трудового арбітражу характерним $є$ «дотримання принципу всебічності і повноти дослідження обставин справи. Сутність цього принципу полягає в тому, що усі органи, що розглядають трудові спори, зобов'язані всебічно і повно досліджувати матеріали справи, витребувати при необхідності додаткові докази, викликати свідків, запрошувати експертів» [2, с. 65]. Дійсно, для вирішення трудових спорів варто повністю з'ясувати як позиції сторін, так й доказовий матеріал. Проте змога залучати свідків та експертів є спірною, адже такий спосіб вирішення трудового спору використовують через швидкість й оперативність розгляду справи, а проведення експертних 
досліджень потребує тривалого часу як для самого дослідження, так й для формування висновку. Щодо свідків, то виникає питання щодо їх неупередженості та достовірності, адже гарантій безпеки реалізації трудових прав такого свідка не передбачено.

Відповідно до ст. 8.8-8.9 Регламенту роботи трудового арбітражу з розгляду і вирішення колективного трудового спору (конфлікту) «рішення приймаються трудовим арбітражем шляхом відкритого фіксованого (поіменного) голосування кожного члена трудового арбітражу. Право внесення пропозицій до проекту рішення трудового арбітражу мають члени примирної коміciï, представники сторін колективного трудового спору (конфлікту), представники Національної служби посередництва і примирення» [3]. Тобто, на відміну від медіації, трудовий арбітраж може проводитись публічно, що дає змогу забезпечити відсутність тиску на будь-яку зі сторін трудового спору. Серед позитивних аспектів такого способу вирішення трудових спорів $є$ змога вносити пропозиції до рішення трудового арбітражу, адже це допомагає самим сторонам краще розібратись із сутністю спору та бажаним кінцевим результатом, а також й полегшує аналітичну роботу для арбітрів. Щодо представників НСПП, то, з одного боку, їх пропозиції матимуть незалежний та неупереджений характер. Разом з тим, саме таку роль мають відігравати арбітри, а отже, представництво НСПП є надлишковим.

Також, відповідно до ст. 6.2 Положення про трудовий арбітраж, «рішення трудового арбітражу розглядається сторонами колективного трудового спору (конфлікту) в семиденний строк після його отримання. Якщо рішення трудового арбітражу не змогло врегулювати розбіжностей між сторонами колективного трудового спору(конфлікту), то причини розбіжностей з обгрунтуванням позицій сторін у письмовій формі доводяться у триденний строк після розгляду до відома кожної із сторін колективного трудового спору (конфлікту) та НСПП» [4]. Таким чином, рішення трудового арбітражу не володіє обов'язковою юридичною силою та викликатиме юридичні наслідки лише у разі спільного задоволення інтересів. У цьому контексті для роботодавця рішення трудового арбітра є бажаним для виконання, якщо воно винесене на його користь або ж передбачає менші збитки, ніж судовий розгляд. Однак саме таке рішення може не вдовольняти трудовий колектив та профспілки, що означатиме або ж проведення страйку, або, власне, звернення до суду. Окремо варто зазначити обов'язок сторін повідомляти про власне рішення щодо намірів у виконанні, яке виступає гарантією права на інформацію та дає змогу вірно розуміти перспективи вирішення трудового спору та захисту своїх прав суб'єктами трудових відносин.

Таким чином, сутністю трудового арбітражу можна вважати оперативний розгляд колективного трудового спору по суті за участі неупередженого та кваліфікованого трудового арбітра (арбітрів), який на основі інтересів сторін приймає власне рішення щодо розв'язання такого спору. Зі свого боку, метою проведення трудового арбітражу є вирішення трудового спору та продовження трудових відносин й господарської діяльності без безпосереднього спілкування між сторонами трудового спору. Тобто перенесення відповідальності приймати рішення у справ на трудового арбітра зменшує конфліктність відносин, а саме рішення робить збалансованим, унаслідок чого збільшується довіра щодо його вірності з боку сторін трудового спору.

У власній роботі щодо трудового арбітражу О.В. Кузніченко звертає увагу на таке: «Те, що процедуру розв'язання конфлікту координує та контролює державний орган - НСПП, також позитивно впливає на термін, якість вирішення розбіжностей, не дає трудовому конфлікту перерости в міжособовий. Власний досвід автора в якості трудового арбітра відділення НСПП у Харківській області свідчить, що сучасні керівники, на жаль, здебільшого орієнтовані на репресивні способи вирішення соціально-трудового конфлікту. Звичайно, це проявляється у посиленні жорстокості режиму на підприємстві та у пошуку винуватого, якого необхідно покарати прилюдно» $[5$, c. 78]. Такий досвід автора свідчить про недостатню ефективність діяльності НСПП щодо пояснення позитивних аспектів використання саме трудового арбітражу для вирішення трудового спору. Причиною низької ефективності можна вважати низький рівень громадської участі, адже навіть за наявності трудового спору члени трудового колективу та самої профспілки мало обізнані щодо своїх прав, їх реалізації та інших можливостей захисту від тиску з боку роботодавця. Крім того, до причин репресивності методів вирішення трудових спорів можна зарахувати незначну якість правового регулювання, адже трудовий арбітраж, посередництва та страйк урегульовані в межах одного нормативно-правового акта, що $є$ недостатнім для вирішення усіх прогалин та колізій. Діяльність трудового арбітражу регулюють НСПП, що не гарантує високої якості юридичної техніки та чіткої відповідності Конституції та законам України по своїй суті.

Отже, на основі проведеного дослідження, можна дійти висновку про такі особливості трудового арбітражу як способу вирішення трудових спорів: 
1) короткостроковість. Таку ознаку зумовлює аналіз правового регулювання, адже усі строки звернення до НСПП щодо ініціювання трудового арбітражу та розгляду ним трудового спору мають чіткий характер та не перевищують максимально 20 днів. Варто вказати, що під час проведення трудового арбітражу дотримується значна частина судових принципів та досліджуються надані сторонами докази й пропозиції. Відповідно, встановлені строки у 10 та 20 днів не $є$ достатніми для того, щоб повною мірою з'ясувати як правові, так й економічні та комунікативні складники трудового спору. Крім того, сторони можуть подавати пропозиції до кінцевого рішення трудового арбітражу, але за встановлені законодавчо строки досягти спільності рішення майже неможливо, а отже, сам конфлікт між суб'єктами не буде вирішено та трудовий спір буде перенесено або ж у суд, або через застосування уже страйку. У цьому контексті короткостроковість проведення трудового арбітражу має бути перевагою, однак строк розгляду до 20 днів не дає змоги повною мірою розкрити його потенціал саме як способу вирішення трудових спорів;

2) підзаконність регулювання. На відміну від попереднього способу вирішення трудових спорів, право на трудовий арбітраж не $є$ закріпленим конституційно. Крім того, на законодавчому рівні регулюванню питання його діяльності приділено лише кілька норм права щодо тривалості, суб'єктів та гарантій проведення трудового арбітражу. Разом із тим потреба щодо закриття прогалин у самому процесі призвела до того, що повноваження самого арбітра, умови його вибору та призначення, а також сам Регламент діяльності трудового арбітражу встановлюються на підзаконному рівні Національною службою посередництва і примирення. Така ситуація має наслідками низький рівень юридичної техніки, застарілість положень щодо гласності та публічності арбітражу, а також невідповідність законодавчим термінам, що особливо стосується назв сторін трудового спору та етапів розгляду справи;

3) змагальність процесу. Така ознака пов'язана з потребою представлення власного бачення сутності трудового спору, його причин та можливостей вирішення кожною із сторін. Зрозумілою $є$ наявність певної суперечності в їх позиціях, що й зумовлює потребу в певному порівнянні таких позицій та їх зіставленні. Змагальність можна розуміти як гарантію рівності можливостей захисту своїх прав сторонами трудового спору, а також як забезпечення його вирішення на користь однієї зі сторін. Однак у межах саме трудового арбітражу особливістю змагальності $\epsilon$ змога винесення рішення, що буде задовольняти інтереси обох сторін, а отже, дотримання змагальності здійснюється задля вірного проведення саме розгляду справи по суті.

Таким чином, серед спільних рис медіації та трудового арбітражу як способів вирішення трудового спору можна зазначити такі:

1) вимоги до суб'єкта проведення;

2) непримусовий характер рішення;

3) складність ініціації.

Першою спільною рисою медіації та трудового арбітражу як способів вирішення трудових спорів є наявність вимог до суб'єктів ї проведення, що особливо стосується саме колективних спорів. Так, перелік арбітрів та посередників $\epsilon$ вичерпним та затверджується НСПП. Для таких осіб обов'язковими є досвід роботи в трудовій та організаційній сфері, проходження спеціального конкурсу, тобто $є$ кваліфікаційні вимоги для отримання нового правового статусу. Спільною також можна вважати територіальну залежність арбітра та посередника, адже вони не можуть здійснювати свої повноваження поза межами юрисдикції органу НСПП, до якого вони прив'язані. Крім того, до цих суб'єктів висувається вимога щодо постійного підвищення кваліфікації, що може полягати у відвідуванні спеціальних курсів та семінарів, що проводяться безпосередньо самою службою. Щодо вимог до медіатора в індивідуальних трудових спорах, то вони більше пов'язані з компетентністю та досвідом особи в трудовій сфері та ії здатності розібратись в особливостях здійснення трудових обов'язків в окремих напрямах виробництва.

Також до спільних рис медіації та трудового арбітражу як способів вирішення трудових спорів можна зарахувати і необов'язковий характер рішень, які ними приймається. Звісно, за попередньою домовленістю, медіаційна угода або ж рішення трудового арбітражу матиме обов'язковий характер для сторін трудового спору, однак з огляду на аналіз національного законодавства стає зрозуміло, що жодного зв'язку із виконавчим провадженням безпосередньо не встановлено. Наслідком такої ситуації $є$ потреба забезпечення прийнятого рішення шляхом звернення до суду. Окремо варто вказати, що необов'язковий характер рішення може мати й позитивний вплив на саму процедуру, адже зменшує рівень психологічного тиску на сторони та дає їм змогу висловлювати та захищати свої позиції в більш неформальній формі, що, своєю чергою, сприяє вірному розумінню сутності спору медіатором чи трудовим арбітром та встановленню такого рішення, що влаштовує обидві сторони, а отже, використання примусу не є необхідним. 
Останньою спільною рисою медіації як способів вирішення трудових спорів є складність ініціації. Щодо трудового арбітражу, то вона полягає у спеціальному зверненні до НСПП, виборі трудових арбітрів, а також й визначення уповноваженої особи від трудового колективу або профспілки, яка буде представляти їхні інтереси під час процесу розгляду справи. Оскільки здебільшого ініціатором проведення трудового арбітражу є сторона працівників, сам доступ до вірної інформації та порядку реалізації права на трудовий арбітраж є ускладненим. Щодо медіації в колективних трудових спорах, то застосовуються аналогічні положення, але для індивідуальних трудових спорів відсутнє спеціальне правове регулювання. Як наслідок, проведення медіації має повністю договірний характер та не передбачає участь держави, відповідно, питання оплати праці медіатора, його незалежності та нейтральності не $є$ забезпеченими.

Зі свого боку, трудовий арбітраж як спосіб вирішення трудового спору володіє відмінними рисами:

1) втручання у спір;

2) публічність;

3) обмежена виборність арбітрів.

Така відмінна риса трудового арбітражу, як втручання у спір, пов'язана із тим, що, на відміну від медіації, де сторони самостійно та лише за координації з боку медіатора віднаходять рішення трудового спору, трудові арбітри визначають таке рішення самостійно. Саме прийняття рішення окремою, незалежною особою дає змогу сторонам бути впевненими в його нейтральності та об'єктивності, а отже, відсутності користі та впливу з боку іншої сторони трудового спору, що заохочує до виконання. Крім того, процедура проведення трудового арбітражу в наближений спосіб до судового розгляду пов'язана з потребою трудових арбітрів детально з'ясувати зміст та підстави трудового спору задля винесення грунтовного рішення. Важливо наголосити на необхідності дослуховуватись до побажань сторін трудового спору та їх бачення найбільш ефективного вирішення справи, адже самостійне винесення рішення та встановлення захисту виключно прав роботодавця чи працівника не розв'язуватиме трудовий спір між сторонами та призведе уже до звернення в суд як орган, що може забезпечити примусовість виконання рішення.

Наступною відмінною ознакою трудового арбітражу є публічність його проведення, що проявляється, насамперед, через залучення держави через повідомлення НСПП про початок трудового арбітражу та про його завершення й відповідні результати. Крім того, доступ до матеріалів справи та самого процесу розгляду справи $\epsilon$ відкритим. Звісно, в разі потреби дотримання державної чи інших видів таємниці встановлюється окремий режим їх повідомлення та врахування, а сама інформації є закритою, що також поширюється на персональні дані сторін трудового спору. Проте під час проведення медіації конфіденційними є усі методи та кількість проведених етапів, що були реалізовані в процесі ії проведення. Також не підлягає розголошенню сам зміст медіаційної угоди, окрім самого факту встановлення домовленостей. Публічність можна пояснити участю трудового колективу як однієї зі сторін трудового спору та наявністю суперечностей саме щодо колективної угоди, а отже, самі підстави проведення трудового арбітражу $є$ публічними, що робить недоцільним дотримання режиму конфіденційності.

Наступна відмінність полягає між трудовим арбітражем як способом вирішення виключно колективних спорів та медіацією, що застосовується для індивідуальних спорів. Так, якщо звертатись до трудового законодавства, стає зрозумілим, що перелік осіб, що вповноважені здійснювати трудовий арбітраж, є затвердженим та постійно регулюються НСПП. Така ситуація має позитивний аспект щодо гарантування державою відповідності таких осіб певним вимогам професійності та змоги притягнення їх до відповідальності. Зі свого боку, потреба в залученні 3 арбітрів для початку трудового арбітражу ускладнює сам процес та його ініціацію. Крім того, саме обмежена кількість трудових арбітрів ускладнює застосування інституту відводу та усунення конфлікту інтересів. Своєю чергою, медіатором в індивідуальних трудових спорах може бути будь-яка особа на вибір самих сторін, а отже, ії нейтральність та незалежність є більш ймовірною.

\section{Список використаних джерел:}

1. Про порядок вирішення колективних трудових спорів (конфліктів) : Закон України від 03.03.1998 р. № 137/98-ВР. Відомості Верховної Ради Украӥни. 1998. № 34. С. 227.

2. Кабанець В.О. Принципи інституту трудових спорів. Форум права. 2006. № 3. С. 61-66.

3. Про затвердження Регламенту роботи трудового арбітражу по розгляду і вирішенню колективного трудового спору (конфлікту) : Наказ Національної служби посередництва і примирення від 08.08.2008 р. № 95. URL: https://cutt.ly/itatdIe (Дата звернення: 10.10.2019) 
4. Про затвердження Положення про трудовий арбітраж : Наказ Національної служби посередництва і примирення від 18.11.2008 p. № 135. URL: https://cutt.ly/KtathLx (Дата звернення: 10.10.2019) C. $76-80$.

5. Кузніченко О.В. Трудові конфлікти: шляхи їх вирішення. Право і Безпека. 2002. № 2.

УДК 349.2

DOI https://doi.org/10.32844/2618-1258.2019.6.15

ЛЮБИМОВ О.к.

\section{КОМПЛЕКС ОСНОВНИХ ПРАВ ПРОФЕСІЙНОГО ПУБЛІЧНОГО СЛУЖБОВЦЯ В УКРАЇНІ}

Стаття присвячена 3'ясуванню комплексу основних прав професійного публічного службовця в Україні. Автор критично аналізує чинне законодавство в частині, що регулює права державних службовців та службовців органів місцевого самоврядування, а також досліджує наукову літературу, в якій вже розглядалась проблематика відповідного елементу правового статусу цих публічних службовців. Особлива увага приділяється ретельній систематизації прав професійних публічних службовців у межах відповідних груп і підгруп, а також з'ясуванню достатності наявних прав професійних публічних службовців й їх змінюваності в процесі триваючої реформи законодавства про публічну службу. Наголошується на тому, що нормативне закріплення прав службовців в органах місцевого самоврядування $є$ дещо вужчим за обсяг прав держслужбовців. При цьому, на відміну від підходу, використаного в Законі України «Про державну службу», Закон України «Про службу в органах місцевого самоврядування» не містить застереження про те, що перелік основних прав відповідних професійних публічних службовців не $\epsilon$ вичерпним. Крім того, звертається увага на те, що в процесі реформи «Перезавантаження влади» відбувається звуження прав публічних службовців, що суперечить європейському праву та рекомендаціям Ради Європи, а також концепції гідної праці публічних службовців в Україні. 3'ясовано, що модернізація системи публічного адміністрування а тій чи іншій мірі позначається на правосуб'єктності професійних публічних службовців, що підтверджує, зокрема, розпочатий у вересні 2019 року етап реформи публічної служби, що отримав назву «Перезавантаження влади» й критикується українськими вченими. Зроблено висновок, що в узагальненому вигляді службово-трудові права публічних службовців складаються з таких груп прав: 1) права публічного службовця як людини і громадянина у сфері праці головним чином; 2) права публічного службовця, пов'язані з належним перебігом службово-трудових обов'язків; 3 ) права публічного службовця, що мають забезпечити належний рівень соціальної безпеки держслужбовців.

Ключові слова: державні службовці, права, правовий статус, професійні публічні службовиі, трудові права.

The article focuses on clarifying the complex of fundamental rights of a professional public servant in Ukraine. The author critically analyzes the current legislation in the part regulating the rights of civil servants and local government officials, as well as examines the scientific literature, which has already examined the problems of the corresponding element of these public servants' legal status. Particular attention is paid to the careful systematization of the rights of professional public servants within the relevant groups

(С ЛЮБИМОВ О.К. - кандидат юридичних наук, помічник судді (Вищий господарський суд 